\author{
Rafał Muster \\ Uniwersytet Śląski w Katowicach \\ (D)tps://orcid.org/0000-0001-8255-7803
}

\title{
Sprawozdanie z działalności Instytutu Socjologii w roku 2019
}

W 2019 roku w Uniwersytecie Śląskim wdrożono szereg zmian, dostosowując funkcjonowanie Uczelni do zmian prawnych i organizacyjnych, wynikających z przyjęcia tzw. Ustawy 2.0. Zmiany te w sposób bezpośredni wpłynęły na funkcjonowanie pracowników Instytutu Socjologii, który obecnie jest jednym z 25 instytutów dyscyplinowych w strukturach Uniwersytetu Śląskiego. Instytut Socjologii — tak, jak i inne instytuty — podzielono na dwa piony: naukowy i dydaktyczny. Dyrektor Instytutu dr hab. prof. UŚ Tomasz Nawrocki odpowiada za jakość prowadzonej działalności naukowej, a Dyrektor Kierunków: socjologia, praca socjalna, polityki miejskie i doradztwo publiczne dr Agata Zygmunt zajmuje się organizacją procesu kształcenia.

Kolejna bardzo istotna zmiana w strukturze Instytutu dotyczyła likwidacji z końcem 2019 roku zakładów, które w 2020 roku zostały zastąpione zespołami badawczymi.

W 2019 roku pracownicy Instytutu Socjologii podejmowali wiele działań mających na celu wzmocnienie rangi i znaczenia jednostki w kraju oraz w środowisku międzynarodowym. Na szczególną uwagę zasługuje pięć opublikowanych monografii w wydawnictwach z tzw. poziomu I zgodnie z wykazem MNiSW. Są to książki: Pawła Ćwikły, Moniki Gnieciak, Kazimiery Wódz Class and Cultural Narratives. The Upper Silesia Case; Krzysztofa Łęckiego Wedtug Tukidydesa. Rozważania socjologa literatury nad „Wojna peloponeska”; Mai Drzazgi-Lech Ślaski Moniuszko: recepcja postaci i twórczości kompozytora na Górnym Śląsku. Studium socjologiczne. T. 2: Mitotwórcze narracje moniuszkowskie w górnoślaskiej kulturze: socjologiczna analiza działalności Ślaskiego Związku Chórów i Orkiestr oraz Opery Ślaskiej w drugiej połowie XX wieku; Urszuli Swadźby, 
Rafała Cekiery, Moniki Żak Wiedza ekonomiczna, praca, przedsiębiorczość, konsumpcja. Świadomość ekonomiczna polskich studentów; Barbary Lewickiej, Marka S. Szczepańskiego Obraz i społeczeństwo. Społeczne ramy kultury artystycznej.

W niniejszym podsumowaniu warto wskazać pracowników, którzy w 2019 roku opublikowali swoje artykuły w czasopismach za co najmniej 40 punktów (zgodnie z wykazem MNiSW). Takie teksty opublikowali: Tomasz Nawrocki, Krzysztof Bierwiaczonek („Studia Socjologiczne”), Robert Pyka (,Studia Regionalne i Lokalne”), Urszula Swadźba z Nicole Horakovą („Economics \& Sociology”), Justyna Kijonka („Przegląd Zachodni”, „Rocznik Polsko-Niemiecki”). Ponadto Kazimiera Wódz we współautorstwie z Witoldem Mandryszem opublikowali tekst w prestiżowym wydawnictwie Edward Elgar Publishing (75 pkt.).

W dorobku publikacyjnym pracowników Instytutu Socjologii za 2019 rok znalazły się również artykuły publikowane m.in. w takich czasopismach, jak: „Problemy Polityki Społecznej”, „International Journal of Research in E-learning”, „Nauka”, „Roczniki Nauk Społecznych”, „Zeszyty Pracy Socjalnej”, „Humanizacja Pracy”, „Polityka Społeczna”, „Sociológia a spoločnost”, „Guliwer”, Rocznik „Muzeum Górnośląski Park Etnograficzny” w Chorzowie, „Socialni Komunikacji. Teoria i Praktika", "Review of Applied Socio-Economic Research REASER". Pracownicy Instytutu opublikowali także 31 rozdziałów w monografiach.

Wzorem lat ubiegłych pracownicy Instytutu brali czynny udział w licznych konferencjach — zarówno w zasięgu ogólnopolskim (64 wygłoszone referaty), jak i międzynarodowym (14 wygłoszonych referatów). Wyraźnie zaznaczyli swoją obecność na XVII Zjeździe Socjologicznym we Wrocławiu, podczas którego takie osoby, jak Krzysztof Bierwiaczonek, Krystyna Faliszek, Grzegorz Gawron, Sławomira Kamińska-Berezowska czy Justyna Kijonka moderowały obrady grup tematycznych. Pracownicy Instytutu Socjologii w ramach programu Erasmus+ w 2019 roku uczestniczyli także w licznych wyjazdach zagranicznych, prowadząc zarówno zajęcia dydaktyczne, jak i badania naukowe.

Zakłady Socjologii Organizacji, Gospodarki i Metodologii Badań Społecznych oraz Socjologii Ogólnej w 10. rocznicę śmierci prof. Władysława Jachera zorganizowały konferencję pt. „Jakość pracy a stan więzi społecznych”.

Kilku pracowników Instytutu otrzymało stypendia zagraniczne: Witold Mandrysz był stypendystą CEEPUS - Central European Exchange Program for University Studies, Barbara Lewicka otrzymała Stypendium badawcze Polsko-Amerykańskiej Komisji Fulbrighta (Fulbright Senior Award), Robert Pyka uzyskał Stypendium Collegium Lyon, Justyna Kijonka otrzymała stypendium NAWA PROM (Międzynarodowa wymiana stypendialna doktorantów i kadry akademickiej) oraz stypendium Mistrzowie Dydaktyki (projekt realizowany w ramach IV osi priorytetowej Programu Operacyjnego Wiedza Edukacja Rozwój, MNiSW, wyjazd studyjny - Uniwersytet w Gandawie, Belgia).

Rafał Cekiera zwyciężył w X edycji „Konkursu na najlepsze zdjęcie lub foto-esej/ foto-reportaż socjologiczny roku". Konkurs zorganizowany został przez czasopismo „Przegląd Socjologii Jakościowej” pod patronatem Sekcji Socjologii Jakościowej i Symbolicznego Interakcjonizmu Polskiego Towarzystwa Socjologicznego. 
Instytut Socjologii w 2019 roku kontynuował współpracę z instytucjami z otoczenia biznesu oraz z jednostkami samorządowymi - m.in. za pośrednictwem funkcjonującej w jej strukturach Rady Programowo-Biznesowej. Warto zaznaczyć, że realizowany w partnerstwie z PUP Tychy projekt „Czas na staż”, którego beneficjentami byli studenci, otrzymał kilka wyróżnień. Realizowany projekt umożliwił studentom zdobycie cennego praktycznego doświadczenia w samodzielnej realizacji badań empirycznych. Studenci odbywali płatne staże w Powiatowym Urzędzie Pracy w Tychach. Inicjatywa ta uzyskała rekomendację do upowszechnienia i wdrożenia na terenie Polski jako jedno z czterech tzw. TOP rozwiązań spośród 32 innowacji testowanych $\mathrm{w}$ projekcie - nominację przyznała kapituła innowacji Białostockiej Fundacji Kształcenia Kadr.

Pracownicy Instytutu Socjologii (Krzysztof Bierwiaczonek, Robert Pyka, Agata Zygmunt i Zbigniew Zagała) na zlecenie Urzędu Miasta w Katowicach przeprowadzili badania i przygotowali raport pt. „Diagnoza uwarunkowań współpracy organizacji pozarządowych z miastem Katowice”.

$\mathrm{Na}$ uwagę zasługuje funkcjonowanie katowickiego oddziału Polskiego Towarzystwa Socjologicznego, którego przewodniczący Adam Bartoszek w 2019 roku zorganizował dziewięć spotkań dyskusyjnych.

W ubiegłym roku w Instytucie Socjologii przeprowadzona została wizytacja Polskiej Komisji Akredytacyjnej. W momencie oddawania tomu „Górnośląskich Studiów Socjologicznych" do druku nie otrzymaliśmy jeszcze stosownej uchwały w przedmiocie oceny programowej dla kierunków: socjologia i praca socjalna.

Katowice, kwiecień 2020 r. 